\title{
The Use of Track-Changes and WhatsApp Group as Media on English Structure Learning in Higher Education
}

\author{
Yorina An'guna Bansa ${ }^{1,{ }^{*}}$ Deka Veronica ${ }^{2, *}$ Ratih Rosita $^{3}$ \\ ${ }^{1,2,3}$ Universitas Muhammadiyah Jambi \\ *Corresponding author. Email: yorinabansa@gmail.com
}

\begin{abstract}
Social media is an alternative environment in practicing language and using language. The use of WhatsApp group nowadays is rapidly increasing, it aims for education. This study to investigate the students' perceptions on the use of track-changes and WhatsApp groups as media for learning English structure subjects. The writers investigated a need to carry out this study as it provides a platform to discover pedagogical implications that would benefit the Y-generation in terms of improving their error-recognition skill from the text given in an Indonesian EFL context. The respondents of this research comprise second-year students completing their bachelor's degree in Economics studies, Universitas Muhammadiyah Jambi, Sumatra, Indonesia. The students' perceptions were measured through a questionnaire. The writer implemented blended learning where the teaching English structure was through face-to-face activity and online learning. Respondents were required to participate in a Whatsapp group where students share their work to recognize and revise errors by using track-changes. The findings showed that 'track changes and WhatsApp group' is an effective media to be implemented in English structure learning and to enhance students' affective domain in English structure skill. The results of this study may be beneficial to EFL educators in incorporating track-changes and WhatsApp groups into their teaching repertoire.
\end{abstract}

Keywords: Blended Learning, Students' perception, Trackchanges, Whatsapp Group.

\section{INTRODUCTION}

The development of information technology (ICT), it makes a big change in education, for example in terms of methods in the teaching and learning process. at this time, social networks have been ranked first with millions of users, mostly students and teenagers. Social networks are used in a variety of purposes with an emphasis on social needs. In this era of all technology, IT and the internet, teachers have an invaluable resource. Unfortunately, this potential has not been fully utilized by teachers in finding resources and applying them to the learning process in the classroom. track-changes, for example, is a program on Microsoft Word that can be used in learning media. Track-Changes aims to correct students' writing, it can involve students in the computerized writing process and encourage students to check, add, edit and rearrange ideas. [1]. This research investigated the use of trackchanges to recognize errors and WhatsApp group to post students' work after using track-changes.
Therefore, the researchers chose to investigate how the students' concessions regarding the use of tractchanges and whatsapp groups as fun and interesting media, especially for $\mathrm{Y}$ generation adolescents who understand ICT. it is used for students in learning to recognize the structural errors of the English language. To carry out research, the WhatsApp group was created specifically to provide space for students, where students can be controlled and directed learning, and provide opportunities for students to apply understanding to the subject structure, they use track-changes to recognize an error in the text given then they share their work and comment their friends' work. In this case, the teacher only acts as a facilitator for those who provide "comments". WhatsApp groups and Track-Changes make it possible to provide live feedback and fun interactions that researchers hope will motivate students to learn English structures like previous studies. (Suthiwartnarueput, T \& Wasanasomsithi, P. 2012)[2] resulted that WhatsApp (WA) group built positive attitudes of students in language learning. To facilitate 
the investigation regarding the use of track-changes and WA groups in learning English structure skill, the researchers formulated the following research questions

a. What are the students' perceptions of their affective domain in using track changes and WhatsApp group in terms of English structure subject?

b. What are the students' perceptions of using track changes and WhatsApp group as a media for English structure learning?

\section{LITERATURE REVIEW}

\subsection{ICT as Media in English Language Teaching and Learning}

Globalization is an ongoing process and will continue to develop without end, but it is closely related to the development and demands of free market capitalism. (Harris, R., Leung, C., \& Rampton, B in Block, D \& Cameron, D)[3]. Since globalization deals with technology development, education purposes should follow this change. Technology is started to apply in education because there is a perspective that science can increase human quality. The increase of ICT use relates directly to computer literacy, information literacy, and human prosperity [4]. It is necessary to be concerned about how technology affects student learning, in other words, does technology make a more effective teacher [5]

Based on Daryanto [6] stated that ICT can be used as teaching media and give some benefits like learning process become more interesting and more interactive, the learning process is not much time consuming, the quality of learning can be increased, teaching and learning process can be done in anywhere and everywhere, and the student attitude can be positive toward ICT used. As Pavio, Bagget \& Kozma [7] indicate that using appropriate media collaboration can enhance students' learning achievement. It can be said that media and material can influence the success of the learning process. It is can be a common issue that the less of media is one of the teaching problems. One of the popular technology is the computer. On the computer, there are track-changes as a program in Microsoft Word. It can be used as media to apply students' understanding of English structure subjects. In web 2.0, there is a WA group that is commonly used by the students to share and comment in daily life. It is also be used as media for English learning. It provides group interaction among students. As Ariani, N \& Haryanto, D(2010)[7] stated that students can interact with each other to discuss learning materials that are given by the teacher or sending their work to the group. Their teacher can be present in this group to give a material summary and comment on the students' work.

\subsection{WA Group and Trackchanges as Media on English Structure Learning}

Mobile devices or applications on smartphones or Androids have rice potential in education, because they can be used in learning. There are many useful cellphone applications for teachers to use, but not all can be used by students according to learning. WhatsApp for example, an application that is popularly used on smart phones, where users are teenagers. WhatsApp first appeared in 2009 in California developed by Jan Koum and Brian Acton. WhatsApp is an online messaging application that has been ranked first in the market. WhatsApp is present on smartphones, tablets and PCs, which is used for instant messaging and provides many features, including sending messages, files, documents, images, audio, video and location. not only that, WhatsApp also comes with Group Communication facilities. In its use, WhatsApp requires an internet network to send messages, while the cost of using it is cheaper than sending SMS. the WhatsApp application is used in all smart mobile devices, especially among students. Realizing this phenomenon, researchers encourage them to apply mobile learning in blended learning via WhatsApp to their students. This aims to determine the effect of WhatsApp in blended learning on EFL undergraduates

Recognizing the role of the English language is another dimension in creating appropriate teaching and learning materials. teachers need to take a different approach to project creation by ELL. whereas students need direct instruction, which can learn through modeling and independent work, and can also work individually, only guided by questions. The ELL guiding approach is used to Revise and edit their language in a written project or assignment. This mediation allows students to develop their language skills through the use of technology and social interactions [8].

Track-changes are used by teachers to provide feedback on students' written work, where text that students provide can be corrected by teachers using trackchanges. Comments are also added to provide suggestions on how students can improve their work. Track-Changes offers the possibility of reviewing and correcting written works. (Dudeney, G \& Hockly, N, 2007: pg.20)[9]. Here is an example of the use of trackchanges in error-recognition.

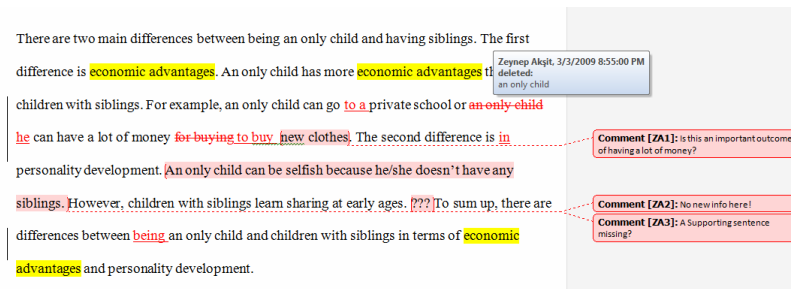

The picture above shows that, comments can be added by students to text documents. those comments will appear in the margins, making them easier to see. 
The Track Changes and Comments feature in Word 2010 and 2007 is located on the Reviewing tab (in Word 2003, they are on the Tools and Insert menu [10]. There are other arguments against this, it is said that it emphasizes the more negative aspects of language learning, because it is not enough for students to recognize the source of the error. students should be encouraged at all times to concentrate on recognizing and producing correct forms. This argument is supported by many psychologists and teachers, who argue that students should not be exposed too much to wrong forms. on the other hand, this type of item is closely related to the skills required when students examine, edit, or proofread any report, article, paper, or essay they have just written in [11].

Throughout the day, the teachers prepare activities for students that have the sole purpose of learning the subject matter. Teachers rarely think about the potential for language learning that can result from the same activities. teachers encourage students to pay attention to the same mistakes, ponder and think about how English works. [8].

\section{METHOD}

\subsection{Participants}

This research was conducted at Muhammadiyah Jambi University, Sumatra, Indonesia in March 2020. A qualitative method survey study exploring the students' perceptions on the use of track changes and WA groups for learning English structure subjects. For this purpose, comprise second-year students completing their bachelor's degree in Muhammadiyah University Jambi, Sumatra, Indonesia were selected as participants in this survey. The respondents were added to a WA group created for this research. The students were asked to create a WA group and invite the teacher to post their work of error recognition from the short story that the teacher gave. Their work was conducted in the classroom and shared in the WA group while they commented on each other and the teacher's comment. Participants were also encouraged to take part in contributing ideas and giving opinions actively. All this was done to create a conducive learning environment, and thus, enable participants to have experience in using track changes and WA groups as a media for English structure learning. In the final stage, they were each required to respond to a questionnaire distributed after two months of participation in the WA group created.

\subsection{Instrument and Data Analysis}

The research design for this study is a qualitative method. The questioner has 2 parts namely affective domain towards track-changes and WA group and students' perceptions toward the use of track-changes and WA group. The questionnaire was done by the respondents in hard copies. The WA Group was created by students namely "Bahasa Inggris RA 12". The teacher gave the short story and they recognized and revised the error based on the theory they learned previously, it is about pronoun, article, and simple tenses.

\subsection{Construction of Questionnaire Items}

The 2 parts of the questionnaire were constructed based on the research questions as stated above.

Part 1: Students' perception to their affective domain in using track-changes and WA group

a. I feel confident learning new computer skills (Trackchanges)

b. I like to use Trackchanges and WA Group for learning purposes

c. I am not accustomed to studying online (WA Group)

d. I feel confident using WA Group

e. I like to study with Trackchanges and WA Group

f. I don't like to participate in the discussion forum (WA Group)

Part 2: Students' Perceptions toward the use of trackchanges and WA group.

a. Trackchanges and WA Group can serve as media for learning English structure

b. Trackchanges and WA Group can allow me to do more interesting and imaginative work.

c. Using track-changes and WA Group is necessary for English structure learning.

d. Increased use of track-changes and WA Group is helpful to my English structure learning

e. English structure learning can be more fun if we use track-changes and WA Group to communicate with peers online

f. It is worthwhile for us to learn how to use the track changes and WA Group for learning purpose

g. The teacher should change the traditional teaching method and adopt track-changes and WA Group as one of the media

h. Students can get distracted easily when they are on the WA Group

i. The use of track changes and WA Group will bring more disadvantages than advantages to students' learning 


\section{FINDING AND DISCUSSION}

In Items 1-7 in part 1, the questionnaire is used to determine respondents' perceptions of how path changes and WA groups affect the affective domain of students in terms of subject structure. Findings are grouped into three broad categories: Cumulative Disagree to represent cumulative data on the percentage of respondents' selection of 'Strongly Disagree' and 'Disagree', Neutral to represent the percentage data for the selection of respondents who disagree or disagree, and Agree other cumulative to represent the percentage of data cumulative 'Agree' and 'Strongly Agree' as shown in Table 1 below:

Table 1. Students'perception of using track-changes and WA group to their affective domain

\begin{tabular}{|c|c|c|c|c|}
\hline $\mathbf{N}$ & $\begin{array}{c}\text { Affective Domain } \\
\text { towards } \\
\text { Trackchanges and } \\
\text { WA Group }\end{array}$ & $\begin{array}{l}\text { Cumu } \\
\text { lative } \\
\text { Agree }\end{array}$ & $\begin{array}{l}\text { Neu } \\
\text { tral }\end{array}$ & $\begin{array}{l}\text { Cumulative } \\
\text { Disagree }\end{array}$ \\
\hline 1 & $\begin{array}{l}\text { I feel confident } \\
\text { learning track-changes } \\
\text { and WA Group for } \\
\text { learning } \\
\text { structure. }\end{array}$ & $53 \%$ & $46 \%$ & $0 \%$ \\
\hline 2 & $\begin{array}{l}\text { I like to use track } \\
\text { changes and WA } \\
\text { groups for English } \\
\text { structure learning. }\end{array}$ & $67 \%$ & $33 \%$ & $0 \%$ \\
\hline 3 & $\begin{array}{l}\text { I am not accustomed } \\
\text { to studying by using } \\
\text { track-changes and } \\
\text { WA groups. }\end{array}$ & $47 \%$ & $53 \%$ & $0 \%$ \\
\hline 4 & $\begin{array}{l}\text { I feel confident using } \\
\text { track-changes and } \\
\text { WA group for learning } \\
\text { English structure }\end{array}$ & $67 \% \%$ & $33 \%$ & $0 \%$ \\
\hline 5 & $\begin{array}{l}\text { I like to study with the } \\
\text { Internet (WA group) }\end{array}$ & $46 \%$ & $33 \%$ & $20 \%$ \\
\hline 6 & $\begin{array}{l}\text { I don't like to } \\
\text { participate } \\
\text { discussion } \\
\text { (WA group) }\end{array}$ & $0 \%$ & $27 \%$ & $73 \%$ \\
\hline
\end{tabular}

From Table 1, it is inferred that more than $50 \%$ of respondents generally agree to the statements which lead to the point that students are confident learning new computer skill to help them in learning English and be confident to use WA Group and share their work in WA Group. In this case, students learn track changes as a tool to recognize and revise errors in the text given. And also more than $50 \%$ of respondents like to use track changes and WA Group for English learning purposes. While 47\% of respondents are not accustomed to using track changes and WA Group for English structure learning. And more than $60 \%$ agree that they like to participate in the discussion forum on WA Group. The data in this table also gives answers to the first research question on what are the affective domain of the students in terms of structure subject.

Table 2: Students' perception of using track changes and WhatsApp group

\begin{tabular}{|c|c|c|c|c|}
\hline $\begin{array}{l}\mathbf{N} \\
\mathbf{0}\end{array}$ & $\begin{array}{l}\text { Students' } \\
\text { Perception }\end{array}$ & $\begin{array}{l}\text { Cumulat } \\
\text { ive } \\
\text { Agree }\end{array}$ & $\begin{array}{c}\text { Neutra } \\
1\end{array}$ & $\begin{array}{l}\text { Cumulat } \\
\text { ive } \\
\text { Disagree }\end{array}$ \\
\hline 1 & $\begin{array}{l}\text { Trackchanges } \\
\text { and WA groups } \\
\text { can serve as } \\
\text { media for } \\
\text { learning English } \\
\text { structure. }\end{array}$ & $60 \%$ & $40 \%$ & $0 \%$ \\
\hline 2 & $\begin{array}{l}\text { Trackchanges } \\
\text { and WA groups } \\
\text { can help me to } \\
\text { do error } \\
\text { recognition in } \\
\text { structure } \\
\text { subjects. }\end{array}$ & $46 \%$ & $27 \%$ & $27 \%$ \\
\hline 3 & $\begin{array}{l}\text { Using track- } \\
\text { changes and } \\
\text { WA group is } \\
\text { necessary for } \\
\text { English } \\
\text { structure subject }\end{array}$ & $60 \%$ & $40 \%$ & $0 \%$ \\
\hline 4 & $\begin{array}{l}\text { Increased use of } \\
\text { track-changes } \\
\text { and WA group } \\
\text { is helpful to my } \\
\text { English } \\
\text { structure } \\
\text { learning. }\end{array}$ & $54 \%$ & $46 \%$ & $0 \%$ \\
\hline 5 & $\begin{array}{l}\text { English } \\
\text { structure } \\
\text { learning can be } \\
\text { more fun if we } \\
\text { use track- } \\
\text { changes and } \\
\text { WA groups to } \\
\text { communicate } \\
\text { with peers } \\
\text { online. }\end{array}$ & $46 \%$ & $54 \%$ & $0 \%$ \\
\hline 6 & $\begin{array}{l}\text { It is worthwhile } \\
\text { for us to learn } \\
\text { how to use the } \\
\text { track changes }\end{array}$ & $33 \%$ & $67 \%$ & $0 \%$ \\
\hline
\end{tabular}




\begin{tabular}{|c|c|c|c|c|}
\hline & $\begin{array}{l}\text { and WA group } \\
\text { for English } \\
\text { structure } \\
\text { learning. }\end{array}$ & & & \\
\hline 7 & $\begin{array}{l}\text { Teachers should } \\
\text { change the } \\
\text { traditional } \\
\text { teaching method } \\
\text { and adopt track- } \\
\text { changes and } \\
\text { WA groups as } \\
\text { one of the } \\
\text { media. }\end{array}$ & $40 \%$ & $60 \%$ & $0 \%$ \\
\hline 8 & $\begin{array}{l}\text { Students can get } \\
\text { distracted easily } \\
\text { when they are on } \\
\text { the Web. }\end{array}$ & $46 \%$ & $33 \%$ & $20 \%$ \\
\hline 9 & $\begin{array}{l}\text { The use of track- } \\
\text { changes and } \\
\text { WA group will } \\
\text { bring more } \\
\text { disadvantages } \\
\text { than advantages } \\
\text { to students' } \\
\text { structure } \\
\text { learning. }\end{array}$ & $0 \%$ & $46 \%$ & $54 \%$ \\
\hline
\end{tabular}

From table 2, it is inferred more than $50 \%$ of respondents agree that track-changes and WA groups can serve as media for English structure learning, using trackchanges and WA group is necessary for English structure subject, increased use of track-changes and WA group is helpful to my English structure learning. While $46 \%$ of respondents agree that Trackchanges and WA group can help me to do error recognition in structure subject, English structure learning can be more fun if we use track-changes and WA group to communicate with peers online, Students can get distracted easily when they are on the Web. And, below $50 \%$ of respondents agree that it is worthwhile for us to learn how to use the track changes and WA group for English structure learning, Teachers should change the traditional teaching method and adopt track-changes and WA group as one of the media. Respondents were neutral when they did not agree or disagree with the items. It can be inferred because they have no idea, track-changes and WA group is the first experience as a media while they learn English structure as they stated on the interview as teacher's observation.

\section{CONCLUSION}

The students' perceptions of their affective domain in using track changes and WA group in terms of English structure subject are respondents are confident learn how to use track changes and WA group and apply it in learning English structure, and they like to use them when learning English structure.

The students' perceptions of using track changes and WA group as a media for English structure learning are respondents supported the use of track-changes and WA group for English structure learning especially those can serve as media for learning English structure, it is necessarily used in English structure subject to make learning more fun, those are helpful to their English structure learning, and using track-changes and WA group will bring more advantages than disadvantages to students' learning especially in this research English structure learning.

\section{REFERENCES}

[1] Z. Aksit, Using 'Trackchanges' in Microsoft Word to Correct Student Writing, Proceedings of the 10th METU ELT Convention, 2010

[2] T. Suthiwartnarueput, \& P. Wasanasomsithi, Effects of using Facebook as a medium for discussions of English grammar and writing of low-intermediate EFL students, Electronic Journal of Foreign Language Teaching, 2012, 9 (2), 194-214.

[4] Munir, Kurikulum Berbasis Teknologi Informasi dan Komunikasi. Bandung: Alfabeta, 2008.

[5] A. Aggarwal, Web-Based Learning and Teaching Technologies: Opportunities and Challenges. University of Baltimore, USA: Idea Group Publishing.

[6] Daryanto, Media Pembelajaran: Perannya Sangat Penting Dalam Mencapai Tujuan Pembelajaran. Yogyakarta: Gavia Media, 2010.

[7] N . Ariani, \& D. Haryanto, Pembelajaran Multi Media Di Sekolah: Pedoman Pembelajaran Inspiratif, Konstruktif, dan Prospektif. Jakarta: PT. Prestasi Pustakaraya, 2010.

[8] T. Erben, R. Ban, \& M. Castaneda, Teaching English Language Learners through Technology. NY: Routledge, 2009.

[9] G. Dudeney, \& N. Hockly, How to Teach English with Technology. NY. Pearson Education, 2007.

[10] Stephen, Use Microsoft Word's Track Changes Feature to Polish Your Documents, 2010, Retrieved from http://blog.gcflearnfree.org/2010/10/12/usemicrosoft-words-track-changes-feature-to-polishyour-documents on June 17, 2013

[11] J.B. Heaton, Writing English Language Tests. USA: Longman Group UK, 1990. 